\title{
PENINGKATAN HASIL BELAJAR MATA PELAJARAN PENDIDIKAN AGAMA ISLAM DENGAN METODE SNOWBALL THROWING
}

\author{
Lili Said Jamili \\ SDN Darmalarang Majalengka, Indonesia \\ lilisaidjamili@gmail.com
}

\begin{abstract}
This research is an effort to improve the learning outcomes of Islamic Religious Education through the Snowball Throwing method for fifth grade students in state elementary schools. This study aims to determine the increase in learning outcomes of Islamic Religious Education subjects Azan and Ikamah material in fifth grade students in State Elementary Schools in 2019/2020 using the Snowball Throwing Method. The application of the method used in this study is Classroom Action Research (CAR). The study was conducted in 2 cycles, each of which had 4 stages: planning, implementing, observing and reflecting. The research subjects were all fifth grade students in SD Negeri totaling 27 students. Data collection techniques using observation sheets, written test questions. Based on the analysis, the results of tests and observations that have been done by researchers concluded that there was an increase in learning activities and student activities so that student learning outcomes increased in each cycle. Thus it can be concluded that learning by using the Snowball Throwing Method can improve P AI learning outcomes in fifth grade students at SD Negeri 2019/2020.
\end{abstract}

Keywords: Learning Outcomes, Islamic Religious Education, Snowball Throwing.

\section{ABSTRAK}

Penelitian ini merupakan upaya untuk meningkatkan hasil belajar Pendidikan Agama Islam melalui metode Snowball Throwing pada siswa kelas V di SD Negeri. Penelitian ini bertujuan untuk mengetahui peningkatan hasil belajar mata pelajaran Pendidikan Agama Islam materi Azan dan Ikamah Pada siswa kelas V di SD Negeri Tahun 2019/2020 dengan menggunakan Metode Snowball Throwing. Penerapan metode yang digunakan pada penelitian ini adalah Penelitian Tindakan Kelas (PTK). Penelitian dilakukan dengan 2 siklus yang setiap siklusnya terdapat 4 tahap yaitu perencanaan, pelaksanaan, observasi dan refleksi. Subjek penelitian adalah seluruh siswa kelas V di SD Negeri sebanyak 27 siswa. Teknik pengumpulan data dengan menggunakan lembar observasi, soal tes tertulis. Berdasarkan analisis, hasil tes dan observasi yang sudah dilakukan peneliti diperoleh kesimpulan bahwa terdapat peningkatan kegiatan belajar dan aktivitas siswa sehingga hasil belajar siswa meningkat pada setiap siklusnya. Dengan demikian dapat disimpulkan bahwa pembelajaran dengan menggunakan Metode Snowball Throwing dapat meningkatan hasil belajar PAI pada siswa kelas V di SD Negeri tahun 2019/2020.

Kata Kunci: Hasil Belajar, Pendidikan Agama Islam, Snowball Throwing.

Submitted November 5, 2019 | December 3, 2019 | Accepted December 5, 2019

\section{Pendahuluan}

Dalam dunia pendidikan, guru, peserta didik dan kurikulum merupakan tiga komponen utama di dalamnya. Guru merupakan komponen utama yang paling penting, karena dia yang mengelola dan melaksanakan proses belajar mengajar. Melalui proses belajar mengajar inilah peserta didik akan mengalami perkembangan ke arah yang lebih baik. Agar hal tersebut dapat terwujud maka diperlukan suasana proses belajar mengajar yang kondusif bagi peserta didik dalam melampaui tahapan-tahapan belajar secara efektif sehingga menjadi pribadi yang percaya diri, inovatif dan kreatif.

Dalam proses pembelajaran Pendidikan Agama Islam penguasaan metodologi pembelajaran merupakan hal yang paling penting bagi seorang guru, karena metodologi yang baik 
akan mampu mewujudkan tujuan pembelajaran. Tujuan pembelajaran pendidikan Agama Islam tidak hanya sekedar menyampaikan pengetahuan kepada peserta didik, namun pembelajaran Pendidikan Agama Islam bertujuan mengarahkan peserta didik agar memiliki kualitas iman, takwa dan akhlak mulia. Oleh sebab itu, dalam pembelajaran seorang guru hendaknya tidak hanya membangun aspek kognitif, namun aspek afektif dan psikomotor peserta didik juga harus dikembangkan.

Tercapainya tujuan pendidikan di Indonesia tidak dapat terlepas dari peran guru, siswa, masyarakat maupun lembaga terkait lainnya. Sebagai salah satu upaya peningkatan kualitas pendidikan menuju tercapainya tujuan tersebut perlu disampaikan suatu upaya perbaikan sistem pembelajaran inovatif yang merangsang siswa untuk mencintai dan akhirnya mau mempelajari secara seksama terhadap suatu mata pelajaran.

Mata pelajaran Pendidikan Agama Islam dalam konsep umum seringkali dipandang sebagai mata pelajaran hafalan yang membosankan. Hal tersebut dapat kita lihat dari adanya ketidaktuntasan siswa kelas V SD Negeri saat ulangan harian pada masing-masing kompetensi dasar, sehingga guru Pendidikan Agama Islam harus mulai mengembangkan sistem pembelajaran inovatif untuk membangkitkan minat siswa terhadap pelajaran Pendidikan Agama Islam. Sehubungan dengan hal di atas metode atau model mengajar yang digunakan oleh guru hendaknya bervariasi sesuai dengan tujuan dan materi yang diajarkan sehingga akan bisa membuat siswa lebih bergairah dalam belajar.

Berdasarkan kesimpulan di atas bahwa pembelajaran pendidikan agama siswa harus dapat bekerjasama atau kooperatif, untuk mewujudkan tujuan pembelajaran tersebut maka disetiap pembelajaran harus digunakan model pembelajaran yang tepat. Salah satu model pembelajaran yang dapat digunakan yaitu model pembelajaran Snowball Throwing. Menurut Rahman (2017) model pembelajaran Snowball Throwing dapat menciptakan pembelajaran menyenangkan bagi setiap peserta didik, berpikir logis dan kritis, berkomunikasi, bekerjasama dalam memecahkan sebuah masalah. Atas dasar itulah penulis melakukan penelitian dengan tujuan meningkatkan hasil belajar siswa dengan menggunakan model pembelajaran Snowball Throwing pada pembelajaran pendidikan agama islam.

\section{Metode Penelitian}

Penelitian ini menggunakan metode Penelitian Tindakan Kelas. Penelitian Tindakan Kelas adalah proses pengkajian masalah pembelajaran di dalam kelas melalui refleksi diri dalam upaya untuk memecahkan masalah tersebut dengan cara melakukan tindakan yang terencana dalam situasi nyata serta menganalisis setiap pengaruh dari perlakuan tersebut (Sanjaya, 2011: 26). Pendapat tersebut sesuai pendapat yang disampaikan oleh Kasbolah (2001: 15), bahwa Penelitian Tindakan Kelas merupakan penelitian tindakan dalam bidang pendidikan yang dilaksananakan dalam kawasan kelas dengan tujuan untuk memperbaiki dan atau meningkatkan kualitas pembelajaran.

Banyak model Penelitian Tindakan Sekolah yang dapat diterapkan, tetapi dalam penelitian ini menggunakan model Kemmis dan McTaggart di mana dalam perencanaannya menggunakan 
siklus sistem spiral yang di dalamnya terdiri dari empat komponen, yaitu rencana, tindakan dan observasi serta refleksi (Sujati, 2000: 23).

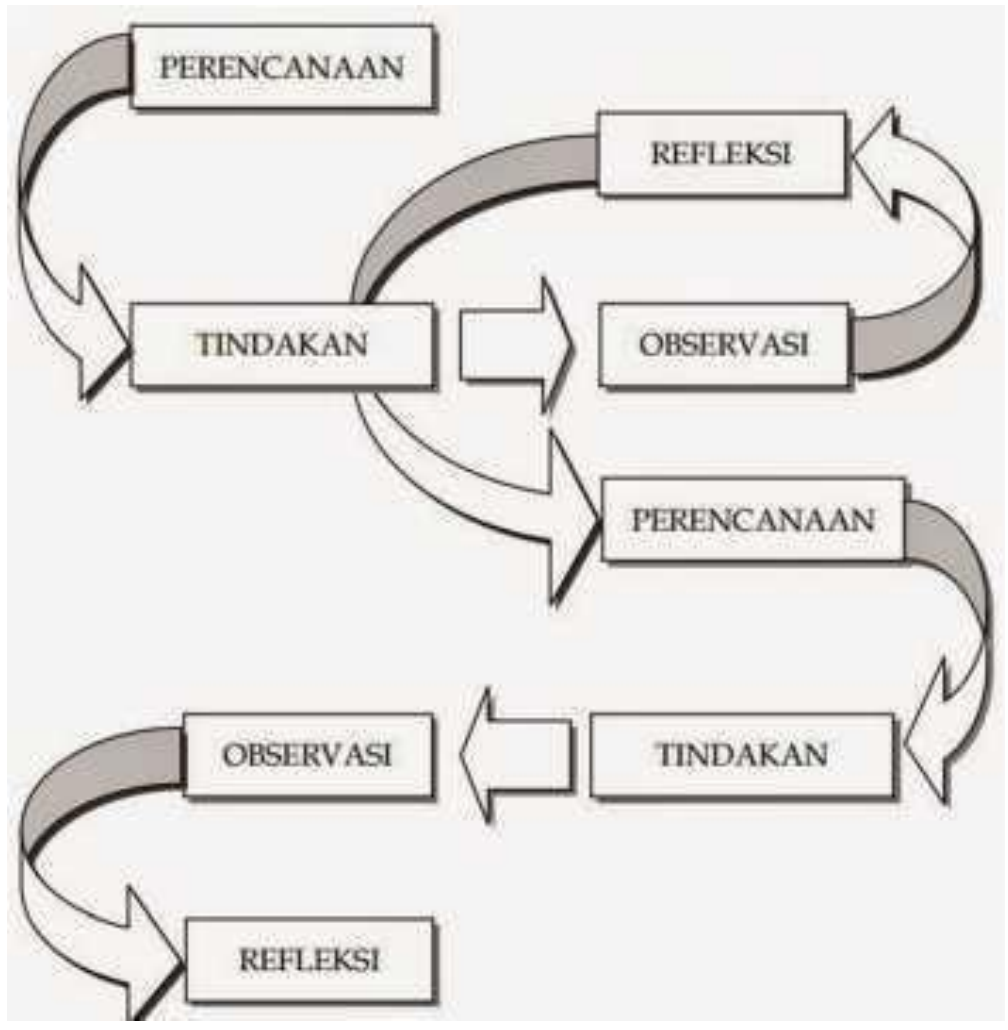

Gambar 1. Model kemmis dan Mc Taggart

Dari gambar 1 di atas maka, penelitian tindakan yang akan dilakukan dapat diuraikan sebagai berikut:

1. Perencanaan (Plan)

Melakukan observasi terhadap situasi atau kemampuan motorik halus anak sebelum dilakukan tindakan, membuat Rencana Kegiatan Harian terlebih dahulu dengan berdiskusi bersama guru kelas (kolaborator), membuat media yang digunakan untuk kegiatan pembelajaran serta mempersiapkan peralatan yang dibutuhkan bersama kolaborator, mempersiapkan lembar observasi yang digunakan untuk mengambil data serta melakukan penilaian dan evaluasi, melakukan setting atau penataan ruang kelas yang mendukung kegiatan pembelajaran.

2. Pelaksanaan (Act) dan Observasi (Observe)

Pelaksanaan dilakukan sesuai dengan perencanaan yang telah dibuat guru kelas dengan peneliti. Pelaksanaan penelitan dilakukan secara fleksibel yaitu bisa berubah sesuai dengan situasi dan kondisi yang ada di lapangan. Guru kelas sebagai kolaborator melaksanakan tindakan yang sudah direncanakan sesuai RKH sedangkan peneliti mengamati proses pembelajaran yang berlangsung.

3. Refleksi (Reflect)

Refleksi dilakukan pada setiap akhir siklus untuk mengetahui apakah kegiatan mewarnai yang diberikan sudah sesuai harapan atau belum serta digunakan peneliti dan kolaborator dalam 
melakukan evaluasi tentang perlu tidaknya melakukan siklus selanjutnya. Selain itu, melalui refleksi dapat melakukan analisis data pada lembar observasi yang telah diisi oleh peneliti dan kolaborator serta melakukan penilaian untuk menyusun rencana perbaikan yang akan dilakukan (Arikunto, 2010).

\section{Hasil dan Pembahasan}

Penelitian yang dilakukan menggunakan Penelitian Tindakan Kelas dengan 2 siklus. Penelitian yang dilakukan adalah dengan mengamati nilai siswa yang telah ada dengan pembelajaran yang sama, untuk membandingkan hasil belajar siswa kelas V SD Negeri sebelum dan sesudah dilakukan tindakan. Data nilai merupakan hasil pembelajaran yang berlangsung, dimana guru dominan dalam pembelajaran sedangkan peserta didik cenderung pasif dan tidak antusias mengukuti pembelajaran sehingga hasil belajar perlu ditingkatkan lagi dengan pemilihan metode yang tepat.

Dari hasil tersebut dapat diketahui bahwa rata-rata hasil nilai harian PAI siswa kelas V SD Negeri hanya 64,07 sedangkan KKM nya 70\%. Jadi hasil ini menunjukkan ketuntasan belajar siswa secara klasikal perlu ditingkatkan. Salah satu cara untuk meningkatkan hasil belajar siswa adalah dengan menerapkan metode Snowball Throwing dalam pembelajaran mata pelajaran PAI khususnya materi azan dan ikamah.

1. Siklus I

a. Perencanaan

Dalam tahap perencanaan peneliti menyusun rencana kegiatan yang akan dilakukan antara lain:

1) Membuat Rencana Pelaksanaan Pembelajaran ( RPP)

2) Mempersiapkan sumber belajar

3) Mempersiapkan daftar pertanyaan sebagai bahan tanya jawab.

4) Mempersiapan lembar pengamatan untuk penilaian.

5) Menentuan tarjet keberhasilan berdasarkan KKM

b. Pelaksanaan

Pelaksanaan tindakan pada siklus I pada bulan November 2016 yang mengacu pada RPP yang telah dipersiapkan. Sebelum proses pembelajaran dimulai guru menyampaikan terlebih dahulu metode pembelajaran yang akan digunakan yaitu dengan metode Snowball Throwing pada siswa. Langkah-langkah yang dilakukan adalah sebagai berikut:

1) Pendahuluan

a) Guru mengucapkan salam dan berdoa bersama.

b) Guru melakukan absensi kehadiran siswa.

c) Guru memberikan motivasi dan mengajukan pertanyaan secara komunikatif yang berkaitan dengan materi pelajaran yang akan di bahas.

2) KegiatanInti

a) Eksplorasi

Guru memberikan penjelasan tentang materi pembelajaran

b) Elaborasi 
(1) Siswadibagimenjadi 4 kelompok

(2) Siswa diperkenalkan lafal azan dan ikamah

(3) Siswa melafalkan azan dan ikamah secara kelompok

(4) Siswa mengulang-ulang lafal azan dan ikamah

(5) Setiap siswa wajib membuat pertanyaan sesuai dengan materi kelompoknya masing-masing yang nantinya akan di buat seperti bola lalu di lempar ketemen yang lain untuk dijawab.

(6) Setiap kelompok membuat resum/kesimpulan yang kemudian dipresentasikan di depan kelas.

c) Konfirmasi

(1) Guru dan siswa menyimpulkan hasil diskusi

(2) Guru member pujian pada siswa yang telah mengikuti pembelajaran dengan baik.

(3) Guru member motivasi agar siswa giat belajar

3) Penutup

a) Guru melakukan klarifikasi dan penguat terhadap hasil evaluasi

b) Evaluasi

c) Berdoa bersama dan salam

Pada akhir siklus dilakukan evaluasi yang berupa tes tertulis untuk mengetahui perkembangan siswa selama mengikuti pembelajaran. Hasil tes tersebut nantinya bisa digunakan sebagai bahan evaluasi untuk tindakan berikutnya.

c. Observasi

Observasi dilakukan dengan mengamati nilai siswa yang telah ada, untuk membandingkan hasil belajar siswa selama menggunakan metode Snowball Throwing. dapat disimpulkan, bahwa ratarata hasil belajar siswa pada siklus I mencapai 75,37 dan persentase ketuntasan siswa sebanyak $66,66 \%$.

d. Refleksi

Berdasarkan data pada siklus I, pembelajaran masih kurang efektif karena selama pembelajaran siswa belum semuanya aktif. Akan tetapi dengan menggunakan metode ini persentase ketuntasan siswa dari 70\% menjadi 75,37\%. Namun hasil ini belum memenuhi target yang diterapkan sehingga perlu satu perbaikan pembelajaran tahap berikutnya.

2. Siklus II

a. Perencanaan

Dalam tahap perencanaan peneliti menyusun rencana kegiatan yang akan dilakukan antara lain:

1) Membuat Rencana Pelaksanaan Pembelajaran (RPP)

2) Mempersiapkan sumber belajar

3) Mempersiapkan daftar pertanyaan sebagai bahan tanya jawab.

4) Mempersiapan lembar pengamatan untuk penilaian.

5) Menentuan target keberhasilan berdasarkan KKM

b. Pelaksanaan

Pelaksanaan tindakan pada siklus II pada bulan November 2016 yang mengacu pada RPP yang telah dipersiapkan hampir sama dengan siklus I hanya saja penekanan pada pemahaman materi ditambah lagi agar anak lebih serius dalam proses pembelajaran. Selama proses pembelajaran aktivitas siswa tetap diawasi oleh guru dan juga peneliti. Setelah selesai pembelajaran 
diadakan evaluasi untuk mengetahui/mengukur kemampuan siswa saat pembelajaran sudah selesai.

\section{Kesimpulan}

Pembelajaran dengan menggunakan metode Snowball Throwing dapat mempermudah guru untuk mengawasi keaktifan siswa saat mengikuti pembelajaran melalui sesi tanya jawab antar kelompok. Keaktifan siswa secara otomatis meningkta dan hasil belajar siswa pun juga meningkat. Dari hasil tes dan observasi yang sudah dilakukan, dikesimpulan bahwa pembelajaran dengan menggunakan metode Snowball Throwing dapat meningkatkan hasil belajar siswa tentang mata pelajaran Pendidikan Agama Kelas 5 SD Negeri DarmalarangTahun 2019/2020. Hal itu terlihat dari nilai rata-rata prestasi siswa dan prosentase kelulusan belajar secara klasikal tiap siklus. Nilai rata-rata siswa pada pra siklus 64,07 dengan prosentase ketuntasan 25,92\%, kemudian pada siklus I nilai rata-rata siswa menjadi 75,37 dengan prosentase ketuntasan 66,66\%, dan terus meningkat pada siklus II dengan nilai rata-rata siswa 86,48 dengan prosentase ketuntasan 92,59\%. Peneliti menyadari bahwa penyusunan skripsi ini masih jauh dari sempurna sehingga masih banyak dijumpai kekeliruan. Oleh karena itu, penulis mengharapkan adanya kritik dan saran demi kesempurnaan penelitian ini. Penulis berharap semoga penelitian ini dapat memberikan manfaat bagi penulis khususnyan dan bermanfaat bagi pembaca pada umumnya dan menambah informasi, motivasi dan pengembangan proses pembelajaran.

\section{Daftar Pustaka}

Arikunto, S. (2007). Prosedur Penelitian Suatu Pendekatan Praktik. Jakarta: PT. Bina Aksara.

Asmani, J. M.. (2016). Tips Efektif Cooperative Learning Pembelajaran Aktif, Kreaktif dan Tidak Membosankan.Yogyakarta: Diva Press.

Baharuddin. (2010). Pendidikan dan Psikologi Perkembangan. Yogjakarta: Ar-Ruz Media.

Fadjar A. (2007). Pendidikan Agama Islam. Aku Anak Muslim untuk Kelas V SD. Klaten: Cempaka Putih.

Ghazali, Imam dkk. (2014). Almumayyaz. Al Qur'an Tajwid Warna Transliterasi per Kata Terjemah per Kata. Bekasi: Cipt Bagus Segara.

Hamalik. (2005). Perencanaan Pengajaran Berdasarkan Pendekatan Sistem. Jakarta: Bumi Aksara.

Kasbolah (2001). Penelitian Tindakan Kelas. Jakarta: Bumi Aksara.

Pusat Bahasa Departemen Pendidikan Nasional. (2003). Kamus Besar Bahasa Indonesia. Jakarta: Balai Pustaka.

Ramayulis. (2014). Metodologi Pendidikan Agama Islam.Jakarta: Kalam Mulia.

Sanjaya. (2010). Penelitian Tindakan Sekolah. Jakarta: Kencana. 
Sardiman. (1986). Interaksi dan Motivasi Belajar Mengajar. Jakarta: PT. Raja Grafindo Persada.

Sujati. (2000). Penelitian Tindaka Kelas. Yogyakarta. FIP. UNY.

Sumadi, S. (2008). Psikologi Pendidikan. Jakarta : Grafindo Persada. hlm. 228.

Sriyanti, Lilik. (2013). Psikologi Belajar. Yogyakarta: Ombak Dua.

Suprijono, Agus. (2013). Cooperative Learning Teori dan Aplikasi Paikem. Yogyakarta: Pustaka Pelajar. 